\title{
Limfoma Kutis dengan Sindroma Hiper IgE
}

\author{
Fahrul $^{1}$, Irza Wahid ${ }^{2}$, Raveinal ${ }^{3}$
}

\begin{abstract}
Abstrak
Limfoma kutis adalah limfoma ekstranoduler yang jarang ditemui dan diklasifikasikan berdasarkan variasi manifestasi klinik, histopatologi, imunohistokimia dan prognosis. ${ }^{1,2} 90 \%$ pasien adalah laki-laki antara usia 20-50 tahun. Kejadian sebesar 1 : 300.000 pertahun. Sindroma Hiper IgE adalah gangguan kompleks imun primer yang ditandai dengan dermatitis atopik dan peningkatan IgE serum yang sangat tinggi serta kerentanan terhadap infeksi jamur dan bakteri. ${ }^{5,6}$ Telah dilaporkan suatu kasus laki-laki, 25 Tahun, keluhan benjolan yang makin membesar/ menyebar pada kulit. Benjolan kemerahan, gatal, tidak nyeri disertai keropeng sejak 6 tahun yang lalu, ditemukan plak eritema, skuama kasar, papul nekrotik, erosi, eksoriasi dan jaringan nekrotik di seluruh tubuh. Laboratorium, leukositosis dan eosinofilia. Peningkatan hebat IgE total $>99.999,90 \mathrm{IU} / \mathrm{ml}$ dan hitung eosinofil absolut $5123 \mathrm{sel} / \mathrm{mm}^{3}$. Histopatologi kesan limfoma kutis. Pemeriksaan imunohistokimia CD3 \& CD 45 positif. Pasien didiagnosis dengan limfoma kutis dengan Sindroma Hiper IgE. Diberikan kemoterapi siklofosfamid, vinkristin dan prednison, serta imunosupresan, emolien dan steroid topikal, dengan respon yang baik.
\end{abstract}

Kata kunci: Limfoma Kutis, Sindroma Hiper IgE

\begin{abstract}
Cutaneous lymphoma is an extranodular lymphoma that is rarely encountered and classified based on variations in clinical manifestations, histopathology, immunohistochemistry and prognosis. ${ }^{1,2} 90 \%$ of patients are men the ages between 20-50 years. The incidence is 1:300,000 per year. Hyper lgE Syndrome is a primary immune complex disorder characterized by atopic dermatitis and a very high increase in serum IgE and susceptibility to fungal and bacterial infections. ${ }^{5,6}$ A case of a man, 25 years old, complained of a lump that grew larger / spread on the skin. Redness, itching, painless lump accompanied by scab since 6 years ago. Physical examination revealed erythema plaques, rough scales, necrotic papules, erosions, excoriations and necrotic tissue throughout the body. Laboratory test found leukocytosis and eosinophilia. Total IgE and absolute eosinophil counts increased considerably, respectively $>99,999.90 \mathrm{IU} / \mathrm{ml} ; 5123 \mathrm{sel} / \mathrm{mm}^{3}$. Histopathology examination found cutaneous lymphoma. Immunohistochemistry test found $C D 3 \& C D 45$ were positive. Patients are diagnosed with cutaneous lymphoma with hyper IgE syndrome. Chemotherapy of cyclophosphamide, vincristine and prednisone was given, as well as immunosuppressants, emollients and topical steroids, with a good response.
\end{abstract}

Keywords: Cutaneous Lymphoma, Hyper IgE Syndrome

Affiliasi penulis : 1. Program Studi Pendidikan Profesi Dokter Spesialis-1 IImu Penyakit Dalam FK Unand/ RSUP Dr. M Djamil Padang 2. Subbagian Hemato Onkologi Medis Bagian IImu Penyakit Dalam FK Unand/ RSUP Dr. M. Djamil Padang 3. Subbagian Alergi Imunologi Bagian IImu Penyakit Dalam FK Unand/ RSUP Dr. M. Djamil Padang

Korespondensi : fahrul5683@gmail.com Telp: +628126724791

\section{PENDAHULUAN}

Limfoma kutis merupakan proliferasi dari limfosit sel $\mathrm{T}$ klonal atau jarang dari natural killer (NK). Limfoma kutis ini diklasifikasikan berdasarkan variasi pada manifestasi klinik, histopatologi, imunofenotyping dan prognosis..$^{1,2}$

Seperempat dari kasus Limfoma Non Hodgkin merupakan limfoma ekstra nodal. Limfoma kutis merupakan kedua terbanyak dari limfoma ekstra nodal setelah limfoma gastrointestinal. Insidennya diperkirakan $1: 100.000 .^{1,2}$

Etiologi limfoma kutis sebagian besar tidak diketahui. Namun terdapat beberapa faktor risiko terjadinya yaitu: imunodefisiensi (severe combinan immunodeficiency, hypogammaglobulinemia, common variable immunodeficiency, wiscott Aldrich syndrome, ataxia telangiectasis), agen infeksius (EBV), paparan herbisisda dan pelarut organik, makanan tinggi lemak hewani, merokok dan paparan sinar ultraviolet. ${ }^{2,3}$

Manifestasi klinis berupa bercak, plak atau tumor, tanda ini bisa terdapat secara bersamaan pada pasien. Pada tahap awalnya pada MF terbentuk multiple eritem, bersisik, kemudian menebal dengan ukuran lesi yang bervariasi. Dengan warna lesi yang bervariasi juga mulai dari oranye sampai merah keunguan. Erupsi kulit tersebut terasa gatal. ${ }^{2,3}$

Diagnosis pada tahap ini sukar ditegakkan, sering pasien mempunyai riwayat dermatitis yang berulang selama 10-20 tahun, yang mungkin telah resisten dengan berbagai terapi. Pada pasien dengan dermatosis berulang dan telah dilakukan berbagai macam modalitas terapi perlu dipertimbangkan untuk dilakukan biopsi. ${ }^{1,2}$

Bercak biasanya lebih awal sampai beberapa bulan bahkan bisa tahunan sebelum terjadi plak, atau bisa juga plak terjadi bersamaan. Plak berbatas tegas bersisik dan lesi yang menimbul yang berwarna merah keunguan dengan indurasi. Lesi pada tahap ini ada 
yang mengalami regresi secara spontan dan ada yang bergabung membentuk plak yang lebar, dengan bentuk anular, dengan batas yang tegas. ${ }^{3,4}$

Pada stadium tumor muncul lesi di berbagai tempat dengan predileksi seperti di wajah, lipatan badan, ketiak, dan pada wanita terdapat pada area bawah mammae. Ini di awali terjadi plak atau bercak CTCL dimana berkembang menjadi fase ganas. Pada poin ini sel telah berprilaku ganas secara biologi, dengan penyebaran dan meluas menjadi nodul Kejadian ini dianggap perkembangan dari T sel klon ganas. Nodul ini berwarna merah kecoklatan atau merah kebiruan dan sering terdapat ulkus dan bisa menjadi infeksi sekunder. Ulkus pada tumor ini menyembuh dengan sendirinya. Perkembangan nodul ini bervariasi. Pasien dengan tumor cenderung berkembang secara aggresif. 1,3

Terapi pada limfoma kutis diberikan sesuai dengan gejala dan staging CTCL. Kemoterapi topikal (nitrogen mustard), electron beam therapy, prosorolen with ultraviolet light (PUVA), retinoid diberikan pada keterlibatan kulit. Regimen terapi sistemik yang diberikan antara lain: CVP (siklofosfamid, vinkristin, prednison), CHOP (siklofosfamid, doksorubisin, vinkristin dan prednison), atau FND (fludarabin, mitoksantron dan deksametason). Juga dapat diberikan analog purin, interferon $\alpha$, denuilukin diftitox, atau terapi antibodi. ${ }^{2,3}$

Prognosis berdasarkan luasnya kulit yang dikenai dan tipenya dan keterlibatan dari kelenjar limfe dan metastase ke jaringan lain. Secara umum pasien dengan MF yang tebatas pada kulit saja mempunyai survival rate 5 tahun sekitar $80-100 \%$, dan sebaliknya pasien dengan keterlibatan kelenjar limfe memperlihatkan survival rate 5 tahun sekitar $40 \%{ }^{2,3}$

Sindrom hiper IgE adalah adalah gangguan kompleks imun primer yang ditandai dengan dermatitis atopik seperti di kulit yang berhubungan dengan peningkatan IgE serum yang sangat tinggi, dan kerentanan terhadap infeksi jamur dan bakteri.. Hampir semua pasien dengan Sindrom Hiper IgE, menderita infeksi stafilokokus berulang, di mulai pada waktu bayi, dan sering melibatkan kulit dan paru-paru. 5,6

Stafilokokus aureus adalah bakteri yang paling sering terisolasi pada pasien Sindrom Hiper IgE. Namun Streptokokus pneumonia, Haemofilus gram negatif, dan bakteri gram negatif lainnya juga ditemukan pada HIES. Infeksi jamur temasuk kandidosis mukokutan dan aspergilosis paru juga sering di temukan pada pasien HIES. Dermatitis atopi biasanya dimulai pada usia neonatal. Pasien dengan dermatitis atopik dengan peningkatan IgE serum yang sangat tinggi dan eosinofilia, tetapi biasanya bebas dari manifestasi alergi lainnya seperti rhinitis, urtikaria, dan reaksi anafilaksis. 5,6

Kelainan kranio fasial pada pasien Sindrom Hiper IgE memiliki penampilan wajah yang khas yang berkembang pada masa anak-anak dan remaja, ditandai dengan asimetris, hidung lebar, dan mata cekung, dengan dahi menonjol, kulit wajah sering memiliki tekstur kasar dan berpori. Diagnosis ditegakkan berdasarkan kecurigaan klinis, eosinophilia dan peningkatan $\mathrm{lgE}$ serum yang sangat tingg melebihi $2000 \mathrm{kU} /$. $^{6,7}$

Pilihan terapi untuk Sindrom Hiper IgE saat ini berupa pencegahan dan pengobatan infeksi kulit dan komplikasi lain yang ditimbulkannya. Penting mengetahui jenis bakteri dan jamur secara dini dan pemberian pengobatan, karena tidak banyak yang menunjukkan gejala infeksi. Tidak ada pengobatan khusus untuk Sindrom Hiper IgE, apabila terjadi eksim yang luas pada kulit diberikan emolien dan steroid topical, profilaks terapi dapat diberikan trimethtropin sulfametoksazol. Terapi infeksi yang disebabkan oleh bakteri dapat diberikan antibiotik yang sesuai. Pemberian imunosupresan seperti kortikosteroid dan siklofosfamid dapat diberikan pada pasien Sindrom Hiper $\lg \mathrm{E}^{5,7}$

\section{LAPORAN KASUS}

Telah dilaporkan suatu kasus laki-laki, 25 tahun dengan keluhan Benjolan pada kulit hampir seluruh tubuh sejak 4 bulan. Benjolan warna kemerahan, berkeropeng kecoklatan, kehitaman, gatal dan tidak nyeri. Awalnya muncul pada punggung sebesar biji kajang hijau sampai sebesar uang logam. Bercak-bercak merah disertai sisik warna putih yang gatal diseluruh tubuh hilang timbul sejak 2 tahun. Penurunan berat badan $15 \mathrm{~kg}$ sejak 1 tahun. Demam sejak 1 bulan. Pemeriksaan fisik ditemukan nodulnodul eritem di atas kulit yang eritem dengan skuama putih kasar, erosi, ekskoriasi, multipel ulkus dengan ukuran 1-3 cm pinggir rata, isi krusta kehitaman, kekuningan dan jaringan nekrotik. Lesi terdistribusi universal bentuk dan susunan tidak khas, batas tidak tegas dan ukuran lentikular-plakat. Laboratorium terdapat leukositosis dan eosinofilia. Peningkatan IgE total $>99.999,90 \mathrm{IU} / \mathrm{ml}$ dan hitung eosinofil absolut $5123 \mathrm{sel} / \mathrm{mm}^{3}$. Histopatologi kesan limfoma kutis. Pemeriksaan imunohistokimia CD3 \& CD 45 positif. Pasien didiagnosis dengan limfoma kutis dengan Sindrom Hiper IgE. Diberikan kemoterapi siklofosfamid, vinkristin dan prednison, serta imunosupresan, emolien dan steroid topikal, dengan respon yang baik.

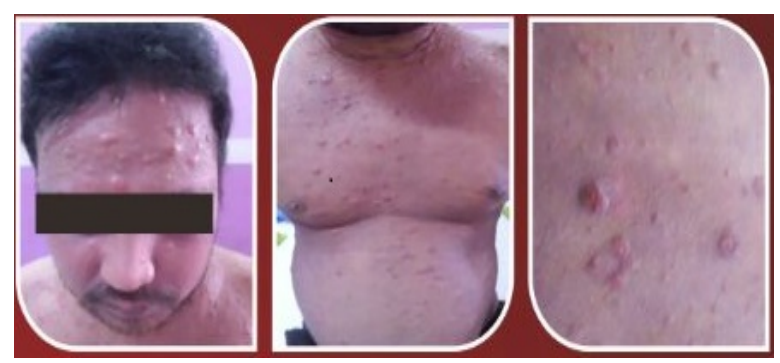

Gambar 1. Sebelum Kemoterapi

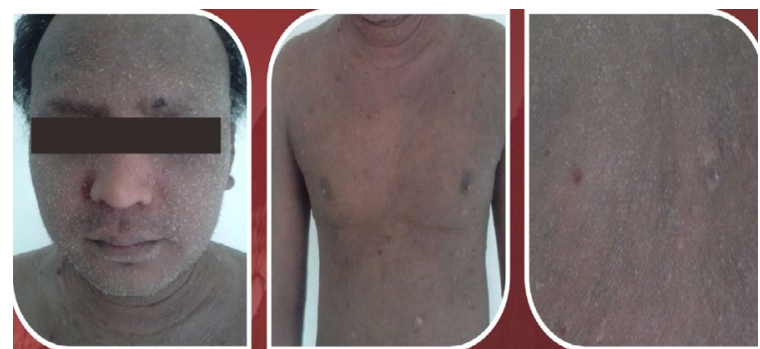

Gambar 2. Setelah Kemoterapi

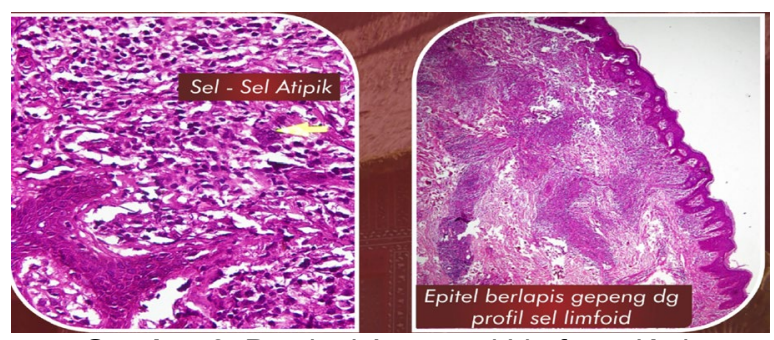

Gambar 3. Patologi Anantomi Limfoma Kutis 


\section{PEMBAHASAN}

Telah dilaporkan pasien laki-laki 25 tahun dengan diagnosis limfoma kutis dengan Sindrom Hiper IgE. Diagnosis limfoma kutis ditegakkan dari lesi kulit yang khas dan pemeriksaan histopatologi. Diagnosis Sindroma Hiper IgE ditegakkan dari riwayat dermatitis atopi, peningkatan eosinofil absolut dan $\operatorname{lgE}$ total. Secara epidemiologi, limfoma kutis merupakan limfoma non hodgkin ekstra nodal kedua terbanyak, dengan insiden 1: 100.000. di negara berkembang masih sedikit laporan tentang kasus limfoma kutis. ${ }^{1,2}$

Manifestasi klinis berupa bercak, plak atau tumor, tanda ini bisa terdapat secara bersamaan pada pasien. Pada tahap awalnya pada MF terbentuk multiple eritem, bersisik, kemudian menebal dengan ukuran lesi yang bervariasi. Dengan warna lesi yang bervariasi juga mulai dari oranye sampai merah keunguan. Erupsi kulit tersebut terasa gatal. Diagnosis pada tahap ini sukar ditegakkan, sering pasien mempunyai riwayat dermatitis yang berulang selama 10-20 tahun, yang mungkin telah resisten dengan berbagai terapi. Pada pasien dengan dermatosis berulang dan telah dilakukan berbagai macam modalitas terapi perlu dipertimbangkan untuk dilakukan biopsi. 2,3

Pada stadium tumor muncul lesi di berbagai tempat dengan predileksi seperti di wajah, lipatan badan, ketiak, dan pada wanita terdapat pada area bawah mamae. Ini di awali terjadi plak atau bercak CTCL dimana berkembang menjadi fase ganas. Pada poin ini sel telah berprilaku ganas secara biologi, dengan penyebaran dan meluas menjadi nodul. Kejadian ini dianggap perkembangan dari $\mathrm{T}$ sel klon ganas. Nodul ini berwarna merah kecoklatan atau merah kebiruan dan sering terdapat ulkus dan bisa menjadi infeksi sekunder. Ulkus pada tumor ini menyembuh dengan sendirinya. Perkembangan nodul ini bervariasi. Pasien dengan tumor cenderung berkembang secara aggressif. ${ }^{1,3}$

Terapi pada limfoma kutis diberikan sesuai dengan gejala dan staging CTCL. Regimen terapi sistemik yang diberikan antara lain: CVP (siklofosfamid, vinkristin, prednison), CHOP (siklofosfamid, doksorubisin, vinkristin dan prednison), atau FND (fkudarabin, mitoksantron dan deksametason). Juga dapat diberikan analog purin, interferon $\alpha$, denuilukin diftitox, atau terapi antibodi. Prognosis berdasarkan luasnya kulit yang dikenai dan tipenya dan keterlibatan dari kelenjar limfe dan metastase ke jaringan lain. ${ }^{2,3}$

Sindrom Hiper IgE adalah adalah gangguan kompleks imun primer yang ditandai dengan dermatitis atopik seperti di kulit yang berhubungan dengan peningkatan $\operatorname{lgE}$ serum yang sangat tinggi, dan kerentanan terhadap infeksi jamur dan bakteri. Hampir semua pasien dengan HIES, menderita infeksi stafilokokus berulang yang di mulai pada waktu bayi, sering melibatkan kulit dan paru. 5,6

Diagnosis berdasarkan kecurigaan klinis, eosinophilia dan peningkatan IgE serum yang sangat tinggi melebihi $2000 \mathrm{kU} / \mathrm{l}$. Sistem skoring yang diciptakan Gimbacher et al dan telah diterima National Institute of Health (NIH) dapat digunakan dalam membantu menegakkan diagnosis HIES. 6,7

Tidak ada pengobatan khusus untuk HIES Pilihan terapi untuk HIES saat ini berupa pencegahan dan pengobatn infeksi kulit dan komplikasi lain yang ditimbulkannya. Penting mengetahui jenis bakteri dan jamur secara dini dan pemberian pengobatan, karena tidak banyak yang menunjukkan gejala infeksi. Pemberian imunosupresan seperti kortikosteroid dan siklofosfamid dapat diberikan pada pasien HIES. ${ }^{5,7}$

\section{SIMPULAN}

Dilaporkan suatu kasus jarang yakni laki-laki 25 tahun dengan diagnosis limfoma kutis dengan Sindroma Hiper IgE. Pemberian kemoterapi siklofosfamid, vinkristin dan prednison, serta imunosupresan, emolien dan steroid topikal memberikan hasil yang baik.

\section{DAFTAR PUSTAKA}

1. Batrani M, Bhawan J, Pitfalls in the diagnosis of Cutaneous Lymphoma. Am J Dermatopathol. 2014; 36(1): 90-100.

2. Gupta A, Sundram U. Cutaneous Lymphoma. J Clin Pathol. 2018; 71: 185-186.

3. Vermeer $\mathrm{MH}$, Willemze R. Limited Effect of Chemotherapy in Cutaneous Lymphoma. Blood Journal. 2015; 125: 4-5.

4. Klemke CD. Cutaneous Lymphomas. JDDG. 2014; 12(1): 7-28

5. Freeman AF, Holland SM. The Hyper IgE Syndromes. Immunol Allergy Clin North Am. 2008; 5: 277.

6. Ferrer AN, Candelas ES, Martin M. IgE Related Chronic Disease and Anti lgE Based Treatment. $\mathrm{J}$ of Immunol Res. 2016; 10: 1-12.

7. Hashemi H, Mohebbi M, Mehravaran S, Mazioumi M, Ardakani HJ. Hyperimmunoglobulin E Syndrome: Genetic, Immunopathogenesis, Clinical Findings, and Treatment Modalities. J Res Med Sci. 2017; 16: 1-10. 